УДК 330.332 .4

Г. М. Винокуров

Иркутский государственный аграрный университет ил. А. А. Ежевского, пос. Молодежный, Российская Федерация

Т. В. Леус

Иркутский государственный аграрный университет ил.А. А. Ежевского, пос. Молодежный, Российская Федерация

\title{
ПУТИ У ЛУЧШЕНИЯ СОСТОЯНИЯ ОСНОВНЫХ ФОНДОВ СЕЛЬСКОХОЗЯЙСТВЕННЫХ ПРЕДПРИЯТИЙ ИРКУТСКОЙ ОБЛАСТИ
}

\begin{abstract}
АНнотАЦия. В сельском хозяйстве для ведения успешного производства необходимы: кадры, имеющие специальную квалификацию, основные фонды и капитал. Основные фонды являются одним из важнейших факторов, который обуславливает собственный капитал предприятия, необходимый для организации процесса производства и ведения финансово-хозяйственной деятельности. От технического состояния основных фондов, особенно их активной части (оборудования), во многом зависят количество и качество производимой продукции, эффективность использования рабочего времени, затраты труда, времени, средств, топлива. В статье рассмотрены структура товарной продукции, источники инвестиций, управление капитальными вложениями, незавершенным строительством, дотации, т. е. факторы, которые имеют большое значение для успешной работы сельскохозяйственных предприятий. Предлагаются пути для улучшения технического состояния основных фондов сельскохозяйственных предприятий Иркутской области.
\end{abstract}

КЛЮЧЕВЫЕ сЛОВА. Основные фонды; дотации; прибыль; собственные средства; амортизация.

ИНФОРМАЦИЯ О СТАТЬЕ. Дата поступления 13 марта 2016 г.; дата принятия к печати 29 марта 2016 г.; дата онлайн-размещения 31 мая 2016 г.

G. M. Vinokurov

A. A. Ezhevsky Irkutsk State Agricultural University, Molodezhny Settlement, Russian Federation

T. V. Leus

A. A. Ezhevsky Irkutsk State Agricultural University, Molodezhny Settlement, Russian Federation

\section{WAYS OF IMPROVING FIXED ASSETS STATE OF AGRICULTURAL ENTERPRISES OF IRKUTSK OBLAST}

\begin{abstract}
Maintaining successful production in agriculture requires the personnel with the special qualifications, the fixed assets and the capital. Fixed assets are one of the major factors which determines the enterprise's own capital necessary for managing the production process and operating the financial and economic activities. The amount of the products made, efficiency of using labor time, costs of labor, time, finance, fuel largely depend on the technical state of the fixed assets, especially, of its active part (equipment). The article considers the structure of the marketable output, investment sources, capital investment management, incomplete construction, grants-in-aid, that is, the factors that have great significance for successful activities of agricultural enterprises. It offers the ways of improving technical state of fixes assets of agricultural enterprises of Irkutsk Oblast.

KEYWORDS. Fixed assets; grants-in-aid; profit; own funds; amortization.

ARTICLE INFO. Received March 13, 2016; accepted March 29, 2016; available online May 31, 2016.
\end{abstract}

Основой благополучия производителей материальных благ является наличие основных фондов. В сельском хозяйстве к ним относят земли, кадры, финансовые источники [1, с. 103]. В настоящее время по каждому составляющему основных

(C) Г. М. Винокуров, Т. В. Леус, 2016

\section{Baikal Research Journal}


фондов имеются проблемы, которые необходимо решать. В статье нами поставлена задача по совершенствованию и устранению недостаточного роста основных фондов и, как следствие, увеличению производства сельскохозяйственной продукции, а также повышению эффективности в деятельности сельскохозяйственных предприятий Иркутской области.

В сельском хозяйстве основными проблемами расширенного воспроизводства основных фондов являются низкая оплата труда, дефицит квалифицированных кадров, недостаточная социальная защита сельского населения [2, с. 93]. В настоящее время принятая денежная политика в стране ухудшила не только уровень жизни населения России на 90 \% [3, с. 125], но и затронула в целом развитие многих отраслей экономики. Капитальные вложения, в первую очередь, зависят от финансового состояния отрасли (прибыли, амортизации, долгосрочных кредитов) и их влияния на состояние реальных основных фондов [4, с. 94].

В целом рентабельность основных отраслей имеет тенденцию к снижению на $2,1 \%$ (табл. 1), в том числе за счет уменьшения растениеводства на $7,1 \%$, прочей сельскохозяйственной продукции на $9,8 \%$, прочих доходов и расходов на $10,2 \%$. По животноводству увеличение рентабельности составило $0,9 \%$, в том числе за счет повышения крупного рогатого скота на $5,4 \%$; скотоводства $-2,1 \%$; свиноводства $-4,0 \%$; мяса птицы - 6,5\% ; птицеводства - 0,1\%. При этом, однако, снизалась рентабельность производства яиц на $11,7 \%$, а молока на $0,7 \%$. Производство овощей остается убыточным, особенно на открытом грунте, так как по растениеводству рентабельность уменьшилась на 7,1 \%, в том числе за счет снижения зерновых на 2,7 \%, картофеля - 21,5\%, овощей - 14,2 \%. Уровень рентабельности товарной продукции сельскохозяйственных предприятий низкий, дотации недостаточные и имеют тенденции к снижению (табл. 2).

Таблица 1

Структура товарной продукиии по сельскохозяйственным предприятиям Иркутской области за 2006-2014 г2.

\begin{tabular}{|c|c|c|c|c|c|c|}
\hline \multirow{2}{*}{$\begin{array}{l}\text { Товарная } \\
\text { продукция }\end{array}$} & \multicolumn{3}{|c|}{$2006-2010$} & \multicolumn{3}{|c|}{$2011-2014$} \\
\hline & $\begin{array}{c}\text { Структу- } \\
\text { ра, \% }\end{array}$ & $\begin{array}{c}\text { Прибыль, } \\
\text { млн р. }\end{array}$ & $\begin{array}{c}\text { Рентабель- } \\
\text { ность, \% }\end{array}$ & $\begin{array}{c}\text { Структу- } \\
\text { ра, \% }\end{array}$ & $\begin{array}{c}\text { Прибыль, } \\
\text { млн р. }\end{array}$ & $\begin{array}{c}\text { Рентабель- } \\
\text { ность, \% }\end{array}$ \\
\hline Зерновые & 7 & 114 & 16,5 & 6,5 & 126 & 13,8 \\
\hline Картофель & 21 & 46 & 27,7 & 1,4 & 13 & 6,2 \\
\hline Овощи & 3,5 & -4 & $-1,0$ & 2,3 & -64 & $-15,2$ \\
\hline Растениеводство & 15,5 & 189 & 12,7 & 12,0 & 102 & 5,6 \\
\hline Крупный рогатый скот & 5,5 & -196 & $-25,3$ & 4,9 & -194 & $-19,9$ \\
\hline Молоко & 17,6 & 256 & 15,1 & 17,5 & 352 & 14,4 \\
\hline Скотоводство & 23,1 & 60 & 2,5 & 22,4 & 158 & 4,6 \\
\hline Свиноводство & 17,8 & 414 & 25,4 & 20,6 & 750 & 29,4 \\
\hline Яйцо & 18,6 & 380 & 24,2 & 15,2 & 270 & 12,5 \\
\hline Мясо птицы & 12,3 & 213 & 11,4 & 22,1 & 538 & 17,9 \\
\hline Птицеводство & 37,9 & 593 & 15,5 & 37,3 & 808 & 15,6 \\
\hline Животноводство & 79,9 & 1070 & 14,7 & 81,2 & 1753 & 15,6 \\
\hline Другие отрасли & 4,6 & -20 & $-3,7$ & 6,8 & -176 & $-13,8$ \\
\hline $\begin{array}{l}\text { Всего / отношение реали- } \\
\text { зованного (за исключением } \\
\text { прочих доходов и расходов) }\end{array}$ & $100 / 88,1$ & 1233 & 13,3 & $100 / 88,7$ & 1663 & 11,6 \\
\hline Прочие доходы и расходы & 11,9 & 598 & 75,0 & 11,3 & 848 & 64,8 \\
\hline Всего & 100,0 & 1831 & 18,2 & 100,0 & 2511 & 16,1 \\
\hline
\end{tabular}

Составлено по данным годовых отчетов Иркутской области по сельскому хозяйству.

\section{Baikal Research Journal}


Таблица 2

Рентабельность товарной продукции по сельскохозяйственныл предприятиял Иркутской области за 2006-2014 22.

\begin{tabular}{|l|r|r|r|r|}
\hline \multirow{2}{*}{ Рентабельность } & \multicolumn{2}{|c|}{$2006-2010$} & \multicolumn{2}{c|}{$2011-2014$} \\
\cline { 2 - 5 } & $\begin{array}{c}\text { Прибыль, } \\
\text { млн p. }\end{array}$ & $\begin{array}{c}\text { Рентабельность, } \\
\%\end{array}$ & $\begin{array}{c}\text { Прибыль, } \\
\text { млн р. }\end{array}$ & $\begin{array}{c}\text { Рентабельность, } \\
\%\end{array}$ \\
\hline Чистая прибыль & 1831 & 16,8 & 2511 & 16,1 \\
\hline Дотации & 1206 & - & 1531 & - \\
\hline Дотации на рубль выручки & 11,5 & - & 9,6 & - \\
\hline
\end{tabular}

Составлено по данным годовых отчетов Иркутской области по сельскому хозяйству.

Сумма инвестиции (табл. 3) постоянно колеблется и зависит от экономической обстановки в стране [5, с. 85]. Удельный вес собственных источников в 2008 г. составил $36 \%$. В дальнейшем он был около $60 \%$, кроме 2014 г., когда снижение произошло до $55 \%$. Основную сумму собстенных средств составляет прибыль и амортизация. Бюджет и инвесторы имеют небольшой удельный вес, из привлеченных средств основную сумму составляют долгосрочные кредиты, которые необходимо возвращать. В последние годы они составляют примерно 30 \% . В целом, долгосрочные кредиты не пользуются большим спросом, особенно у финансово-устойчивых предприятий [6, с. 68].

Таблица 3

Инвестиции и источники их форлирования

на сельскохозяйственных предприятиях Иркутской области за 2008-2014 22.

\begin{tabular}{|l|r|r|r|r|r|r|r|}
\hline \multicolumn{1}{|c|}{ Показатель } & 2008 & 2009 & 2010 & 2011 & 2012 & 2013 & 2014 \\
\hline Собственные средства & 1239 & 1438 & 1430 & 2009 & 2665 & 1970 & 1977 \\
\hline Прибыль & 752 & 776 & 728 & 1017 & 1435 & 801 & 1151 \\
\hline Амортизация & 430 & 573 & 597 & 350 & 885 & 1138 & 800 \\
\hline Прочие & 57 & 89 & 105 & 242 & 345 & 31 & 25 \\
\hline Привлеченные средства & 2204 & 720 & 684 & 1123 & 1202 & 1145 & 1590 \\
\hline Бюджет & 288 & 59 & 91 & 217 & 329 & 283 & 312 \\
\hline Кредиты долгосрочные & 1876 & 564 & 579 & 849 & 858 & 858 & 1071 \\
\hline Инвесторы & 38 & 97 & 14 & 57 & 15 & 4 & 6 \\
\hline Итого & 3443 & 2158 & 2114 & 3132 & 3867 & 3115 & 3567 \\
\hline Приобретенная техника & 1701 & 934 & 901 & 1348 & 1682 & 2436 & - \\
\hline Строительство & 1385 & 677 & 625 & 920 & 1079 & 2436 & - \\
\hline Доходные вложения & 76 & 237 & 262 & 366 & 405 & 476 & 76 \\
\hline
\end{tabular}

Составлено по данным годовых отчетов Иркутской области по сельскому хозяйству.

Использование прибыли на капитальные вложения (табл. 4) сельскохозяйственных предприятий Иркутской области за период 2008-2014 гг. варьируется в пределах 30-60 \% . При этом доля прибыли, используемая для потребления, занимает незначительный удельный вес, следовательно, для капитальных вложений она ограничена, так как значительная часть расходуется на погашение долгосрочных кредитов.

Использование амортизации на капитальные вложения колеблется от 50 до $80 \%$, т. е. расходуется не полностью. Одна из причин - это убыточность или низкая рентабельность, которая ведет к использованию амортизации для покрытия убытков или для их потребления [7, с. 90].

В строительстве значительный удельный вес занимают затраты незавершенного производства. Цикл организации строительства зависит от многих условий: наличия проектно-сметной документации, подрядчиков, материалов, земли, кадров, источников и других факторов (табл. 5) [8, с. 20]. Основной критерий незавершен-

\section{Baikal Research Journal}

электронный научный журнал Байкальского государственного университета

2016. T. 7, № 3

ISSN 2411-6262

2016, vol. 7 , no. 3 
ного производства - это срок строительства, поэтому в целом предприятие заинтересовано сократить его.

Таблица 4

Использование прибыли и алортизации на капитальные вложения сельскохозяйственных предприятий Иркутской области за 2008-2014 г2., млн р.

\begin{tabular}{|l|r|r|r|r|r|r|r|}
\hline \multicolumn{1}{|c|}{ Показатель } & \multicolumn{1}{|c|}{2008} & 2009 & 2010 & 2011 & 2012 & 2013 & 2014 \\
\hline Прибыль & 1816 & 1741 & 1996 & 2057 & 2409 & 2504 & 2893 \\
\hline Капитальные вложения & 752 & 776 & 728 & 1017 & 1435 & 801 & 1151 \\
\hline Процент использования & 41 & 45 & 38 & 49 & 60 & 32 & 40 \\
\hline Амортизация & 671 & 837 & 948 & 1063 & 1296 & 1389 & 1578 \\
\hline Капитальные вложения & 430 & 573 & 597 & 750 & 886 & 1138 & 800 \\
\hline Процент использования & 64 & 68 & 63 & 71 & 68 & 82 & 51 \\
\hline
\end{tabular}

Составлено по данным годовых отчетов Иркутской области по сельскому хозяйству.

Таблица 5

Незавершенное строительство сельскохозяйственных предприятий Иркутской области за 2010-2014 22.

\begin{tabular}{|l|r|r|r|r|r|}
\hline Незавершенное строительство & \multicolumn{1}{|c|}{2010} & 2011 & 2012 & 2013 & 2014 \\
\hline На начало года & 491 & 628 & 629 & 825 & 752 \\
\hline Затраты & 1322 & 1664 & 2036 & 2467 & 1843 \\
\hline Списано & 54 & 396 & 79 & 152 & 145 \\
\hline Принято & 1153 & 1261 & 1763 & 2410 & 1824 \\
\hline На конец года & 607 & 635 & 823 & 729 & 657 \\
\hline
\end{tabular}

Составлено по: Приангарье: год за годом : стат.сб. Иркутск : Иркутскстат, 2014. С. 156-167.

В современных условиях одной из причин увеличения сроков строительства является недостаток средств. Этот фактор, как правило, ведет к удорожанию себестоимости, так как в период остановки строительства необходимо увеличить затраты на охрану, освещение и другие расходы, связанные с содержанием объекта [9, с. 26].

Из-за низкой рентабельности сельскохозяйственной отрасли для нормального ведения производства необходима поддержка в виде льготного налогообложения и дотаций по различным направлениям (табл. 6) [10, с. 3]. Из-за постоянной инфляции уровень выделяемых дотаций постоянно меняется. В период финансовых трудностей сумма поддержки сокращается. В 2009-2010 гг. и 2013-2014 гг. суммы дотации снижаются, наибольший уровень был в 2008 г. (20,6 к. на 1 р. выручки), наименьший в 2010 и 2014 гг. (7,5 к. на 1 р. выручки и 8,1 к. на 1 р. выручки, соответственно). С сокращением дотаций уменьшается и сумма средств, выделяемых прямо на инвестиции в виде частичной оплаты по приобретению сельскохозяйственной техники. Как правило, на эти цели дотации предоставляют из областного бюджета. Средства, выделяемые из федерального бюджета, более стабильны и колеблются в пределах 4-10 к. на 1 р. выручки, при этом наибольшее значение было в 2008 г.

Основные фонды сельскохозяйственных предприятий Иркутской области представлены в виде машин и оборудования, объектов строительства, стоимости земли, животных, объектов мелиорации, многолетних насаждений. Стоимость основных средств с учетом инфляции постоянно изменяется [11, с. 11] в сторону увеличения (табл. 7), также как и начисленная амортизация. Так, в 2010 г. первоначальная стоимость основных фондов была 13706 млн р., а в 2011 г. — 14939 млн р. (прирост составил 1233 млн р.); в 2012 г. - 17672 млн р. (прирост - 2733 млн р.), а в 2013 г. - 19025 млн р. (прирост - 1353 млн р.); в 2014 г. - 21262 млн р. (прирост 2237 млн р.). Из-за резкого увеличения стоимости объекта по годам износ относительно невелик и за анализируемый период (2010-2014) отличается незначительно.

\section{Baikal Research Journal}


Поддержка производства сельскохозяйственных предприятий Иркутской области за 2008-2014 22.

\begin{tabular}{|l|r|r|r|r|r|r|r|}
\hline \multicolumn{1}{|c|}{ Показатель } & 2008 & 2009 & 2010 & 2011 & 2012 & 2013 & 2014 \\
\hline $\begin{array}{l}\text { Получено бюджетных средств (из федераль- } \\
\text { ного бюджета) }\end{array}$ & $\begin{array}{r}1907 \\
(924)\end{array}$ & $\begin{array}{r}852 \\
(677)\end{array}$ & $\begin{array}{r}819 \\
(480)\end{array}$ & $\begin{array}{r}1344 \\
(646)\end{array}$ & $\begin{array}{r}1608 \\
(556)\end{array}$ & $\begin{array}{r}2038 \\
(835)\end{array}$ & $\begin{array}{r}1509 \\
(742)\end{array}$ \\
\hline Расходы на поддержку отрасли & 1542 & 852 & 787 & 1108 & 1168 & 1195 & 1342 \\
\hline Растениеводство & 180 & 203 & 235 & 400 & 364 & 681 & 576 \\
\hline Животноводство & 217 & 104 & 208 & 356 & 404 & 742 & 497 \\
\hline Прочие & 1145 & 565 & 344 & 352 & 439 & 268 & 268 \\
\hline Инвестиции (приобретение техники) & 365 & - & 33 & 644 & 440 & 346 & 168 \\
& $(365)$ & & $(33)$ & $(236)$ & $(391)$ & $(334)$ & $(162)$ \\
\hline Выручка & 9228 & 10 & 11 & 13 & 15 & 16 & 18 \\
& & 434 & 878 & 676 & 416 & 283 & 614 \\
\hline Дотации на 1 р. выручки (из федерального & 20,6 & 8,4 & 7,5 & 9,8 & 10,4 & 12,5 & 8,1 \\
бюджета), к. & $(10,0)$ & $(6,5)$ & $(4,3)$ & $(4,7)$ & $(3,6)$ & $(5,1)$ & $(4,0)$ \\
\hline
\end{tabular}

Составлено по данным годовых отчетов Иркутской области по сельскому хозяйству.

Таблица 7

Динамика основных средств по сельскохозяйственным предприятиям Иркутской области за 2010-2014 г2., млн р.

\begin{tabular}{|l|r|r|r|r|r|r|}
\hline \multirow{2}{*}{ Год } & \multicolumn{2}{|c|}{ Первоначальная стоимость } & \multicolumn{2}{|c|}{ Начислено амортизации } & \multicolumn{2}{|c|}{ Износ, \% } \\
\cline { 2 - 7 } & Начало года & Конец года & Начало года & Конец года & Начало года & \multicolumn{1}{c|}{ Конец года } \\
\hline 2010 & 13706 & 14939 & 5151 & 5980 & 37,6 & 40,0 \\
\hline 2011 & 14939 & 17852 & 5980 & 6790 & 40,0 & 38,0 \\
\hline 2012 & 17672 & 19549 & 6717 & 7537 & 38,0 & 38,6 \\
\hline 2013 & 19025 & 21516 & 7369 & 8200 & 38,7 & 38,1 \\
\hline 2014 & 21262 & 22522 & 8182 & 9302 & 38,5 & 41,3 \\
\hline
\end{tabular}

Составлено по данным годовых отчетов Иркутской области по сельскому хозяйству.

Поступление основных средств по сельскохозяйственным предприятиям Иркутской области больше, чем их выбытие в 2010 г. в 2,6 раза; 2011 г. — в 3,7 раза; 2012 г. — в 2,3 раза; 2013 г. — в 2,8 раза; 2014 г. - в 1,8 раз (табл. 8). Проведя анализ и соответствующие расчеты по сельскохозяйственным предприятиям Иркутской области, мы получили следующий результат. Анализ технического состояния основных фондов осуществляется путем сопоставления коэффициентов между собой. Сопоставление коэффициента обновления основных фондов с коэффициентом выбытия позволяет установить направления изменения основных фондов: если отношение коэффициентов меньше единицы, то основные фонды направляются преимущественно на замену устаревших; если отношение коэффициентов больше единицы, новые основные фонды направляются на пополнение действующих. В нашем примере основные фонды за все годы исследования направлялись на пополнение действующих фондов, что обеспечивало их значительный прирост. Коэффициент годности основных фондов показывает, какую долю составляет их остаточная стоимость от первоначальной стоимости за определенный период. В нашем случае, количество техники и скота сокращается, поэтому показатели годности из-за стоимости значительно завышены.

Анализ технического состояния основных фондов на сельскохозяйственных предприятиях Иркутской области требует от них разработки программы внедрения новой техники и ввода новых производственных объектов. При этом особое внимание необходимо обратить на внедрение прогрессивного оборудования, на увели-

\section{Baikal Research Journal}

электронный научный журнал Байкальского государственного университета 
чение доли высокомеханизированных и автоматизированных производственных процессов, повышающих конкурентоспособность предприятия и его продукции. В целом, из-за низкой рентабельности отрасли сумма долгосрочной задолженности растет (табл. 9). Наибольшие поступления были в 2012 г. и составили 2016 млн р., в последующие годы поступления несколько снижаются: 2011 г. - 1042 млн р.; 2013 г. - 1461 млн р.; 2014 г. - 863 млн р.

Таблица 8

Движение основных средств по сельскохозяйственным предприятиям Иркутской области за 2010-2014 г2., млн р.

\begin{tabular}{|l|r|r|r|r|r|r|r|r|}
\hline \multirow{2}{*}{ Год } & \multicolumn{4}{|c|}{ Первоначальная стоимость } & \multicolumn{3}{|c|}{ Коэффициенты } \\
\cline { 2 - 9 } & Начало года & Поступило & Выбыло & Конец года & роста & обновления & выбытия & годности \\
\hline 2010 & 13706 & 2126 & 833 & 14939 & 0,09 & 0,14 & 0,07 & 0,60 \\
\hline 2011 & 14939 & 4003 & 1090 & 17852 & 0,19 & 0,22 & 0,07 & 0,62 \\
\hline 2012 & 17672 & 3255 & 1441 & 19549 & 0,11 & 0,17 & 0,08 & 0,61 \\
\hline 2013 & 19025 & 3791 & 1369 & 21516 & 0,11 & 0,18 & 0,07 & 0,62 \\
\hline 2014 & 21261 & 2856 & 1598 & 22522 & 0,16 & 0,13 & 0,08 & 0,59 \\
\hline
\end{tabular}

Составлено по данным годовых отчетов Иркутской области по сельскому хозяйству.

Таблица 9

Имеющаяся долгосрочная кредиторская задолженность сельскохозяйственных предприятий Иркутской области в 2011-2014 г2., млн р.

\begin{tabular}{|r|r|r|r|r|r|r|}
\hline \multirow{2}{*}{ Год } & \multicolumn{2}{|c|}{ Поступило } & \multicolumn{2}{|c|}{ Выбыло } & \multicolumn{2}{|c|}{ Остаток } \\
\cline { 2 - 7 } & Сумма долга & $\begin{array}{c}\text { Начисление } \\
\text { процента }\end{array}$ & Погашено & $\begin{array}{c}\text { Списание уплаты } \\
\text { процентов }\end{array}$ & Начало периода & Конец период \\
\hline 2011 & 1042 & 26 & 697 & 7,1 & 2774 & 3137 \\
& $(872)$ & $(26)$ & $(529)$ & $(7,1)$ & $(2269)$ & $(2631)$ \\
\hline 2012 & 2016 & 27 & 1509 & 9,8 & 3138 & 3663 \\
& $(1764)$ & $(27)$ & $(1310)$ & $(9,8)$ & $(2631)$ & $(3102)$ \\
\hline 2013 & 1461 & 29 & 1229 & 13,7 & 3583 & 3836 \\
& $(1269)$ & $(29)$ & $(1049)$ & $(13,7)$ & $(3048)$ & $(3283)$ \\
\hline 2014 & 863 & 25 & 840 & $(10$ & $(3838$ & 3676 \\
& $(434)$ & $(25)$ & $(748)$ & $(2851)$ \\
\hline
\end{tabular}

Примечание. В скобках представлена задолженность по кредиту.

Составлено по данным годовых отчетов Иркутской области по сельскому хозяйству.

Одной из причин непогашения долгосрочной задолженности является недостаток собственных средств. В сельском хозяйстве часто кредиты предоставляются по льготной ставке, поэтому сумма начисления относительно невысокая. Из-за малой суммы собственных средств ориентация на долгосрочные кредиты не имеет перед собой будущего, так как их необходимо гасить.

За 2009-2014 гг. наличие техники в сельскохозяйственных предприятиях Иркутской области значительно сократилось: трактора - 31,8 \%; специальные трактора - 41,3\% ; сеялки - 37,8 \% ; картофелесажалки - 15,2 \% ; сенокосилки $-27,8 \%$; комбайны зерновые $-34,4 \%$; комбайны кормоуборочные $-27,8 \%$; комбайны картофелеуборочные - 19,7 \%; дождевальные установки - 61,5\%; жатки - 32,2 \% ; доильные установки - $18,7 \%$; транспортеры для уборки навоза $-11,2 \%$; грабли $-26,4 \%$; пресс-подборщики $-6,8 \%$; автомобили грузовые $29,9 \%$, за исключением раздатчиков кормов, количество которых увеличились на $8,2 \%$ (табл. 10). Отметим, что при таком материальном обеспечении производство имеет прирост в $1 \%$.

\section{Baikal Research Journal}


Таблица 10

Диналика наличия техники в сельскохозяйственных предприятиях Иркутской области за 2009-2014 22.

\begin{tabular}{|l|r|r|r|r|r|r|r|}
\hline \multicolumn{1}{|c|}{ Спецтехника } & 2009 & 2010 & 2011 & 2012 & 2013 & 2014 & $2014 / 2009$ \\
\hline Трактора & 2707 & 2437 & 2342 & 2182 & 1973 & 1845 & 68,2 \\
\hline Специальные трактора & 213 & 209 & 182 & 156 & 147 & 125 & 58,7 \\
\hline Сеялки & 1316 & 1199 & 1132 & 1073 & 891 & 818 & 62,2 \\
\hline Картофелесажалки & 33 & 32 & 31 & 32 & 30 & 28 & 84,8 \\
\hline Сенокосилки & 263 & 248 & 231 & 212 & 234 & 190 & 72,2 \\
\hline Комбайны зерновые & 971 & 893 & 891 & 835 & 692 & 697 & 65,6 \\
\hline Комбайны кормоуборочные & 234 & 212 & 27 & 187 & 169 & 169 & 72,2 \\
\hline Комбайны картофелеуборочные & 66 & 70 & 70 & 66 & 58 & 53 & 80,3 \\
\hline Дождевальные установки & 13 & 7 & 6 & 7 & 6 & 5 & 38,5 \\
\hline Жатки & 326 & 300 & 293 & 266 & 228 & 221 & 67,8 \\
\hline Доильные установки & 208 & 202 & 206 & 172 & 169 & 169 & 81,3 \\
\hline Раздатчики кормов & 97 & 103 & 103 & 105 & 104 & 105 & 108,2 \\
\hline Транспортеры для уборки навоза & 322 & 316 & 324 & 309 & 305 & 286 & 88,8 \\
\hline Грабли & 182 & 162 & 164 & 155 & 144 & 134 & 73,6 \\
\hline Пресс-подборщики & 207 & 183 & 193 & 209 & 190 & 193 & 93,2 \\
\hline Автомобили грузовые & 2089 & 1793 & 1754 & 1705 & 1674 & 1464 & 70,1 \\
\hline
\end{tabular}

Составлено по: Приангарье: год за годом : стат. сб. Иркутск : Иркутскстат, 2014. С. 156-167.

Динамика потребления электроэнергии на сельскохозяйственных предприятиях Иркутской области за этот же период также имеет тенденцию к понижению (табл. 11). Снижение потребления электроэнергии за анализируемый период произошло, во-первых, из-за спада производства в результате низкого платежеспособного спроса сельскохозяйственных предприятий, во-вторых, из-за перехода к дифференцированному учету электроэнергии, так как это технико-экономическая проблема, решение которой отвечает интересам и поставщиков, и потребителей электроэнергии. Для объектов агропромышленного комплекса, оснащенных электротепловыми установками, электронасосными агрегатами, электрооборудованием для сушки сена и другой подобной техникой, экономические предпосылки внедрения дифференцированного учета электроэнергии очевидны: особое значение дифференцированный учет приобретает в связи с принятием Правительством РФ постановления об отмене льготных тарифов [12, с. 9]. С их отменой появляются дополнительные стимулы к переходу потребителей агропромышленного комплекса на дифференцированный учет электроэнергии, дающий возможность компенсировать в определенной степени негативные последствия лишения льготных условий оплаты электроэнергии.

Таблица 11

Динамика потребления электроэнергии по Иркутской области в 2009-2014 22., $\mathrm{kBm}$

\begin{tabular}{|l|c|c|c|c|c|c|r|}
\hline Потребление электроэнергии & 2009 & 2010 & 2011 & 2012 & 2013 & 2014 & $2014 / 2009$ \\
\hline Получено & 350184 & 301568 & 278089 & 272991 & 266630 & 269293 & 75,5 \\
\hline Затрачено & 350773 & 302228 & 278729 & 275148 & 319057 & 318500 & 90,8 \\
\hline $\begin{array}{l}\text { В том числе на производ- } \\
\text { ственные цели }\end{array}$ & 325191 & 288522 & 271258 & 265826 & 261050 & 256104 & 78,8 \\
\hline $\begin{array}{l}\text { Общая энергетическая мощ- } \\
\text { ность, л. с. }\end{array}$ & 1062297 & 989465 & 1016284 & 976507 & 672939 & 817401 & 76,9 \\
\hline
\end{tabular}

\section{Baikal Research Journal}

электронный научный журнал Байкальского государственного университета 
Количество имеющейся у сельскохозяйственных предприятий Иркутской области техники на начало 2008 г. значительно больше, чем на конец 2014 г. (табл. 12). Значительно уменьшились энергетические мощности в 2014 г. по сравнению с 2008 г. (на $32,2 \%$ ). Потребление электроэнергии на производственные цели также снизилось на 22,7 . Такое снижение можно охарактеризовать как с положительной, так и с отрицательной стороны технического перевооружения.

Таблица 12

Поступление техники на сельскохозяйственные предприятия Иркутской области в 2008-2014 г2.

\begin{tabular}{|l|r|r|r|r|}
\hline \multicolumn{1}{|c|}{ Спецтехника } & Начало 2008 г. & $2008-2014$ & Конец 2014 г. & Удельный вес \\
\hline Тракторы & 3177 & 586 & 1970 & 29,7 \\
\hline Сеялки & 1518 & 199 & 818 & 24,3 \\
\hline Картофелесажалки & 32 & 14 & 28 & 50 \\
\hline Сенокосилки тракторные & 295 & 73 & 190 & 38,4 \\
\hline Комбайны зерновые & 111 & 236 & 627 & 37,6 \\
\hline Комбайны кормоуборочные & 256 & 61 & 143 & 42,7 \\
\hline Комбайны картофелеуборочные & 64 & 20 & 53 & 37,7 \\
\hline Жатки & 355 & 98 & 221 & 44,3 \\
\hline Доильные установки & 218 & 72 & 169 & 42,6 \\
\hline Раздатчики кормов для КРС & 66 & 64 & 105 & 61 \\
\hline Транспортеры для уборки навоза & 287 & 132 & 286 & 46 \\
\hline Грабли тракторные & 187 & 53 & 134 & 39 \\
\hline Пресс-подборщики & 184 & 92 & 193 & 47,7 \\
\hline Автомобили & 1910 & 359 & 1464 & 24,5 \\
\hline
\end{tabular}

Составлено по: Приангарье: год за годом : стат.сб.Иркутск : Иркутскстат, 2014. С. 156-167.

Для улучшения деятельности сельскохозяйственных предприятий необходимо восстановить производство сельскохозяйственной техники в России, интенсификацию и модернизацию производства по приемлемым, ниже импортных ценам; произвести дальнейшее укрепление мелких производителей в производстве, переработке и продаже сельскохозяйственной продукции. Для прочности материальной базы вместо льготного кредитования через банки увеличить дотации непосредственно конкретным сельскохозяйственным предприятиям на покупку техники, сырья и материалов. Следует добиться ситуации, когда количество списанных материальных ценностей будет меньше, чем купленных или введенных в производство в натуральных показателях. Это даст возможность повысить благосостояние сельскохозяйственных предприятий.

\section{Список использованной литературы}

1. Финансовый менеджмент. Проблемы и решения / под ред. А. З. Бобылевой. - М. : Юрайт, 2012. - 903 с.

2. Винокуров Г. М. Инвестиции, осуществляемые в форме капитальных вложений / Г. М. Винокуров // Вестник Иркутской государственной сельско-хозяйственной академии. - 2014. - № 64. - С. 124-130.

3. Винокуров Г. М. Прибыль и рентабельность в сельских хозяйствах Иркутской области / Г. М. Винокуров, Т. В. Леус // Власть и управление на Востоке России. - 2015. № 4 (73). - С. 90-96.

4. Винокуров Г. М. Состояние основных фондов и источники их обновления в сельском хозяйстве : монография / Г. М. Винокуров, С. И. Винокуров, Т. В. Леус. - Иркутск : Изд-во Иркут. гос. с.-х. акад., 2015. - 144 с.

\section{Baikal Research Journal}


5. Винокуров М. А. Новая экономическая реальность и политика современной России / М. А. Винокуров. - М. : Аргументы недели, 2014. - 136 с.

6. Зубова Т. А. Основные тенденции и проблемы развития сельского хозяйства Брянской области / Т. А. Зубова / Экономика и управление. - 2015. — № 4 (125). - С. 89-93.

7. Ильина Е. А. Инвестиционная привлекательность сельскохозяйственных предприятий / Е. А. Ильина // Экономический анализ: теория и практика. - 2013. — № 1 (304). C. 19-24.

8. Наконечная О. А. Финансирование воспроизводства основных фондов в сельском хозяйстве региона / О. А. Наконечная // Экономика и бизнес: теория и практика. - 2015. № 6 . - C. $25-27$.

9. Попов Д. Н. Управление воспроизводством основных фондов в агроформированиях / Д. Н. Попов // Экономические науки. - 2013. - № 4 (32). - С. 1-5.

10. Тяпкина М. Ф. Инвестиционная привлекательность предприятия: теория, методология, практика / М. Ф. Тяпкина, Е. А. Ильина. - Иркутск : Изд-во Иркут. гос. с.-х. акад., 2014. - $160 \mathrm{c}$.

11. Шутьков А. Экономическая политика: проблемы воспроизводства и импортозамещения / А. Шутьков, С. Шутьков // Экономика сельского хозяйства России. — 2015. — № 5. C. $7-14$.

12. Ушачев И. Г. Экономические проблемы воспроизводства в АПК России / И. Г. Ушачев. - М. : Энцикл. рос. деревень, 2003. - 455 с.

\section{References}

1. Bobyleva A. Z. (ed.). Finansovyi menedzhment. Problemy i resheniya [Financial management. Problems and solutions]. Moscow, Yurait Publ., 2012. 903 p.

2. Vinokurov G. M. Investments in form of capital contribution. Vestnik Irkutskoi gosudarstvennoi sel'sko-khozyaistvennoi akademii = Bulletin of Irkutsk State Agrarian University named after Ezhevsky, 2014, no. 64, pp. 124-130. (In Russian).

3. Vinokurov G. M., Leus T. V. Profit and profitability in rural households of Irkutsk Oblast. Vlast' i upravlenie na Vostoke Rossii = Power and Administration in the East of Russia, 2015, no. 4 (73), pp. 90-96. (In Russian).

4. Vinokurov M. A. Sostoyanie osnovnykh fondov i istochniki ikh obnovleniya $v$ sel'skom khozyaistve [State of fixed assets sources of their renewal in agriculture]. Irkutsk State Agrarian University named after Ezhevskiy Publ., 2015. 144 p.

5. Vinokurov G. M. Novaya ekonomicheskaya real'nost' i politika sovremennoi Rossii [New economic reality and modern Russia's policy]. Moscow, Argumenty nedeli Publ., 2014. $136 \mathrm{p}$.

6. Zubova T. A. Main tendencies and problems of developing agriculture in Bryansk Oblast. Ekonomika i upravlenie = Economics and Management, 2015, no. 4 (125), pp. 89-93. (In Russian).

7. Il'ina E. A. Investment attractiveness of agricultural enterprises. Ekonomicheskii analiz: teoriya i praktika = Economic Analysis: Theory and Practice, 2013, no. 1 (304), pp. 19-24. (In Russian).

8. Nakonechnaya O. A. Financing reproduction of fixed assets in regional agriculture. Ekonomicheskii analiz: teoriya i praktika = Economic Analysis: Theory and Practice, 2013, no. 1 (304), pp. 19-24. (In Russian).

9. Popov D. N. Managing reproduction of fixed assets in agricultural household. Ekonomicheskie nauki = Economic Sciences, 2013, no. 4 (32), pp. 1-5. (In Russian).

10. Tyapkina M. F., Il'ina E. A. Investitsionnaya privlekatel'nost' predpriyatiya: teoriya, metodologiya, praktika [Company's investment attractiveness: theory, methodology, practice]. Irkutsk State Agrarian University named after Ezhevsky Publ., 2014. 160 p.

11. Shutkov A., Shutkov S. Economic policy: problems of reproduction and import substitution. Ekonomika sel'skogo khozyaistva Rossii = Economy of Russia's Agriculture, 2015, no. 5, pp. 7-14. (In Russian).

12. Ushachev I. G. Ekonomicheskie problemy vosproizvodstva v APK Rossii [Economic problems of reproduction in Russia's agribusiness]. Moscow, Entsiklopediya rossiiskikh dereven' Publ., 2003. 455 p.

\section{Baikal Research Journal}




\section{Информация об авторах}

Винокуров Геннадий Михайлович - доктор экономических наук, профессор, кафедра финансов и анализа, Институт экономики управления и прикладной информатики, Иркутский государственный аграрный университет им. А. А. Ежевского, 664038, Иркутская область, Иркутский район, пос. Молодежный, e-mail: march-kitten@mail.ru.

Леус Талара Владилировна - аспирант, кафедра финансов и анализа, Институт экономики управления и прикладной информатики, Иркутский государственный аграрный университет им. А. А. Ежевского, 664038, Иркутская область, Иркутский район, пос. Молодежный, e-mail: march-kitten@mail.ru.

\section{Authors}

Gennady M. Vinokurov - Doctor habil. (Economics), Professor, Chair of Finance and Analysis, Institute of Economics management and Applied Computer Science, A.A. Ezhevsky Irkutsk State Agricultural University, Molodezhny Settlement, Irkutsk District, Irkutsk Oblast, Russian Federation; e-mail: march-kitten@mail.ru.

Tamara V. Leus - PhD Student, Chair of Finance and Analysis, Institute of Economics management and Applied Computer Science, A.A. Ezhevsky Irkutsk State Agricultural University, Molodezhny Settlement, Irkutsk District, Irkutsk Oblast, Russian Federation; e-mail: march-kitten@mail.ru.

\section{Библиографическое описание статьи}

Винокуров Г. М. Пути улучшения состояния основных фондов сельскохозяйственных предприятий Иркутской области / Г. М. Винокуров, Т. В. Леус // Baikal Research Journal. 2016. — T. 7, № 3. — DOI : 10.17150/2411-6262.2016.7(3).13.

\section{Reference to article}

Vinokurov G. M., Leus T. V. Ways of improving fixed assets state of agricultural enterprises of Irkutsk Oblast. Baikal Research Journal, 2016, vol. 7, no. 3. DOI : 10.17150/24116262.2016.7(3).13. (In Russian).

\section{Baikal Research Journal}

